\title{
Conceptual design of offshore platform supply vessel based on hybrid diesel generator-fuel cell power plant
}

\author{
Maria C. Díaz-de-Baldasano, Francisco J. Mateos, Luis R. Núñez-Rivas, Teresa J. Leo
}

\begin{abstract}
- Conceptual design of PSV ship with hybrid diesel electric-FC power plant is presented.
- Two methanol-fed $250 \mathrm{~kW}$ SOFC systems are installed on board with 21 days autonomy.

- Cogeneration heat from SOFC allows answering hot water needs on board.

- Optimized hull design allows sailing with SOFCs and only one diesel generator.

- At ECO-Speed operation mode pollutant emissions are notably reduced.
\end{abstract}

\section{A B S T R A C T}

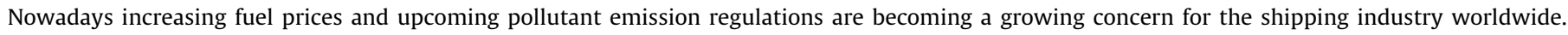

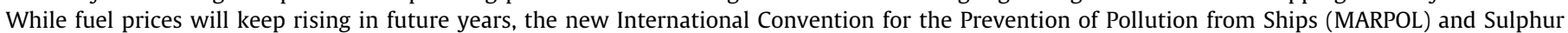

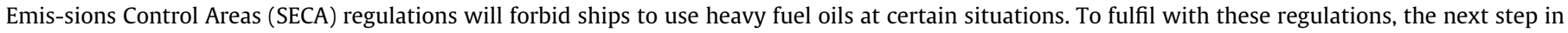

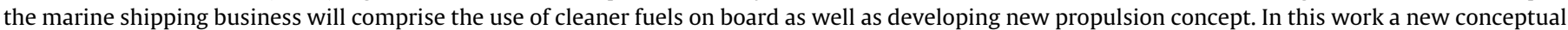

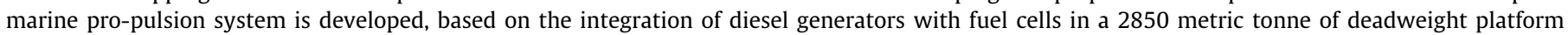

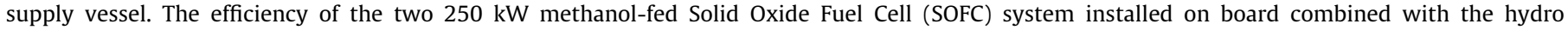

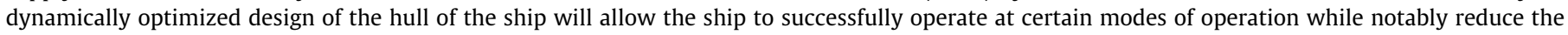

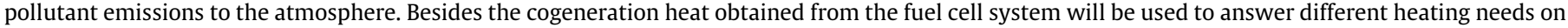
board the vessel.

\section{Introduction}

Currently, important consideration is given to the environment and renewable energies with a view to promoting a cleaner world. It is known that the global energy availability and sustainable development is a big challenge and big efforts have to be undertaken in all energy consumption sectors, being the shipping industry one of the most urged to addressing changes in order to comply with upcoming pollutant emissions regulations. Thus the new International Convention for the Prevention of Pollution from Ships (MARPOL) and Sulphur Emissions Control Areas (SECA) regulations $[1,2]$ will forbid ships to use heavy fuel oils at certain situations. At the same time, given the concerns for high oil prices and fossil fuel depletion, ship owners and operators are looking for different ways of generating power on board. As a result, the shipping industry is promoting the use of cleaner fuels on board [3] as well as developing new propulsion concepts, as the fully electric powered ship, or All-Electric Ship [4,5]. Within this context, several countries and companies have begun to focus on a new horizon not yet sufficiently explored: the installation of fuel cells on board ships [6-9]. Fuel cells could eventually represent a major advance in the shipping business as they have higher efficiency than traditional internal combustion engines, allow flexibility of fuel utilization, show low or zero emissions and operate with low vibration and noise level.

The use of fuel cells in surface vessels is still fairly innovative and therefore, currently remains at the Research, Development \& Demonstration stage [7-9]. In respect of surface ships, Polymer Electrolyte Membrane (PEMFC), Phosphoric Acid (PAFC), Molten Carbonate (MCFC) and Solid Oxide (SOFC) Fuel Cells can be suitable to be installed on board. Suitability will depend, on one hand, on the characteristics and fuel used by the fuel cell under consideration and, on the other hand, on power consumption on board. 
Operating temperature of these fuel cells ranges from $80{ }^{\circ} \mathrm{C}$ (PEMFC) to $850{ }^{\circ} \mathrm{C}$ (SOFC) and efficiency varies from $40 \%$ to $85 \%$. This last value corresponds to the case of high temperature fuel cells (MCFC and SOFC) using cogeneration, i.e., combining heat and power (CHP) production. On board, fuel cells can be used for the following:

- Auxiliary Power Units (APUs).

- Small scale power generation.

- Main propulsion system for boats and small vessels.

- Low power propulsion in special modes of operation of large vessels.

- Hot water/vapour generation when CHP is possible.

Fuel availability represents an important issue to be taken into account and fuel cells can use either hydrogen or gases with a high content in hydrogen, such as methane and liquid hydrocarbons, or alcohols, such as methanol. When fuels other than hydrogen are used, incorporation of a reforming process is required in many cases.

The power consumption on board surface ships ranges from a few hundred kilowatts to more than one hundred megawatts. Therefore, adequacy of a fuel cell type to be installed on board, fed with a specific fuel, must be assessed taking into account the characteristics and specifications of the vessel under consideration. Moreover, it can be said that in general and contrary to that occurs with small surface vessels (low power surface ships), PEMFC and PAFC are ideal for cargo ships that transport hydrogen, but they are not considered so suitable for other types due to hydrogen's low volumetric energy density and the fact that it involves installing enormous storage tanks that can only offer limited autonomy. For this reason, in addition to the difficulties of obtaining it in harbours, hydrogen may not always be a good choice as a fuel for large surface vessels (high power surface ships), and other alternatives should be considered [9].

Regarding fuel cells installed on board surface ships, a variety of marine fuel cell demonstration projects are currently in development or have been launched in recent years [7-9]. Within the small surface vessels category, PEMFC fuel cells are the most commonly used. Two examples of small surface vessels, one in operation and the other under study, are to be mentioned here. Thus, the Zemships project [10] developed the Alsterwasser, a 100-passengers boat which sails the waters of the river Alster in Hamburg since 2008. It carries a hybrid propulsion plant consisting of a battery and two $48 \mathrm{~kW}$ PEM fuel cells with hydrogen storage at 350 bar [11]. Not yet going into service, the Hydrogen Hybrid Harbour Tug (HHHT) project [12] is developing the Green Tug, an 85 metric tonne of dead weight tug equipped with hybrid fuel cell/diesel power plant. Two $100 \mathrm{~kW}$ PEMFC fed with hydrogen stored at 430 bar are intended to be installed on board, so that it is expected a higher efficiency and substantial reduction in emissions, $\mathrm{SO}_{x}$ and $\mathrm{NO}_{x}$ by $90 \%$ and $\mathrm{CO}_{2}$ by $50 \%$. The vessel will use fuel cells for standby, fuel cells and batteries for deployment and transit, and fuel cells, batteries and diesel generators (gensets) for ship assistance operations. Sailing in green mode, the vessel will achieve zero emissions.

When projects devoted to large surface vessels are examined, the use of a variety of fuels and fuel cell types becomes evident $[8,9]$. Two significant projects are mentioned here. In 2009, in the frame of the FellowSHIP project [13], the Viking Lady, a 5900 metric tonne of dead weight offshore supply vessel [14], started serving in oil platforms in the North Sea with high-temperature MCFC $\left(550-700^{\circ} \mathrm{C}\right)$ fed by liquefied natural gas (LNG) to generate part of the energy used on board. It is worth to mention that the power needs of supply vessels range from about 2 to $5 \mathrm{MW}$. Four diesel engines are used for main propulsion. The $320 \mathrm{~kW}$ MCFC fuel cell installed on board, which works together with batteries, is able to generate electrical power for the ship but only to operate at low speed and low power, the appropriate conditions for use in port. This feature is of capital interest because the vessel is designed to sail in the North Sea, where there are strict regulations on exhaust emissions. Through this project it was determined that not only a decrease in $\mathrm{CO}_{2}$ emissions can be achieved, but that $\mathrm{NO}_{x}$ emissions are decreased by 180 tons. A decrease in fuel consumption has also been observed. Nevertheless no information on cogeneration (CHP) features concerning this project is given. Another important project concerning large surface vessels is the METHAPU project [15] whose main objective consists on validating the use of methanol as a marine fuel. An APU [16] for commercial vessels, based on a $20 \mathrm{~kW}$ methanol-fed SOFC fuel cell, has been developed by Wärtsilä and demonstrated on board a Walennius Wilhemsen car carrier, Undine, in 2010. Emissions reduction has been demonstrated, with no $\mathrm{CO}$ or $\mathrm{SO}_{2}$, low $\mathrm{NO}_{x}$ and $40 \%$ of $\mathrm{CO}_{2}$ reduction. As a consequence, higher power SOFC systems for marine applications are currently being developed. Therefore, SOFC fuel cells, which are high temperature fuel cells operating at $650-850{ }^{\circ} \mathrm{C}$ with possibility of cogeneration, is another type of fuel cell to be considered for use on large ships, not simply as APU systems but as part of their power plant.

Then, this work presents the conceptual design of a large surface ship, the so called Balmat offshore supply vessel, Fig. 1, with an innovative hybrid power plant based on heat engines and high temperature SOFC fuel cells using methanol as a fuel. The ship, a 2850 metric tonne of dead weight platform supply vessel, incorporates two fuel cell systems of $250 \mathrm{~kW}$ each, taken at the stage of conceptual design also. In this project, SOFC fuel cells are incorporated to the power plant supplying $500 \mathrm{~kW}$, not as an APU system, and in a certain mode of operation the electrical power from the fuel cell system represent about $20 \%$ of the vessel's needs. Calculations to estimate the heating needs on board have also been performed verifying that cogeneration heat obtained from the high temperature fuel cells installed can satisfy such demand. To make this project come true, the shapes of most offshore vessels built up to date have been considered in order to calculate and optimize the Balmat shapes and properly integrate the fuel cell units within the ship. This new configuration provides the ship with an electric propulsion system that gives her a high manoeuvrability while in operation and a lower fuel consumption, as well as less environmental impact as she is able, based on her hydrodynamic optimized hull shapes, to sail inside an offshore platform park by means of the power output generated by the fuel cells and only one diesel generator. To develop this work the latest rules and regulations, applicable to marine fuel cell installations have been taken into account [17].

Therefore, it can be claimed that this new concept of offshore supply vessel represents an improvement of knowledge in naval architecture as much as in the application and generation of energy, based on the integration of fuel cells on the power system, which represents the first steps of a technological breakthrough that will be part of future developments in the shipbuilding industry.

\section{Ship's main particulars}

\subsection{Ship chosen to integrate the fuel cell system}

Prior to the design of integration of the fuel cell system an important decision had to be made: what type of vessel would be the right candidate to integrate the fuel cell system? The answer is mainly subject to the dimensions of the fuel cell system and to its power output. An easy solution could be to integrate the fuel cell system in large vessels as tankers or ferries. However the amount of electrical power needed on board is so important that adding fuel cells to the system would not make a relevant 

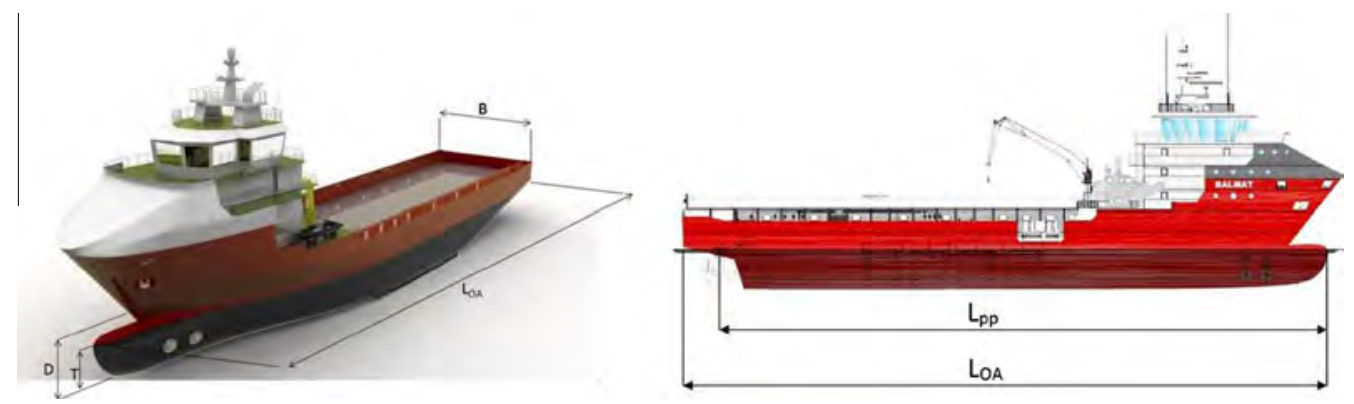

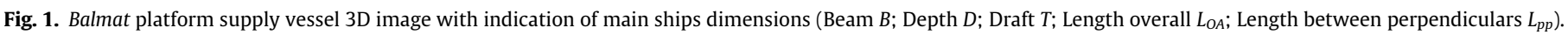

improvement to the original design, at this time. According to the scope of this work the right vessel must have certain physical characteristics to carry the fuel cells but, most importantly, its electrical power needs must be partially covered by means of the fuel cell system. The vessel chosen is a Platform Supply Vessel (PSV), a multi-role vessel designed to operate in offshore platforms. PSVs are used mainly to carry drilling materials and goods from shore to the platform. Depending on her role, these vessels electrical needs usually range, as previously said, from $2500 \mathrm{~kW}$ to $5000 \mathrm{~kW}$. That makes this kind of ship an ideal candidate to operate the fuel cell system as in certain modes of operation the amount of electrical power delivered by the fuel cells could be up to $20 \%$ of the vessel's needs.

The decision to integrate fuel cells in a PSV has also a potential favourable economic impact since the environment protection rules for $\mathrm{NO}_{x}$ reduction in defined Emission Control Areas (ECAs) will apply after January 2016 [18]. Besides ECA port authorities are imposing strict rules on sulphur content in heavy fuels (HFO). As offshore vessels spend $10 \%$ of the year at sea in ECA zones and $18 \%$ of the time in ECA zone ports, fuel cell propulsion with fuels other than HFO will probably lead to exempt these vessels from paying pollution taxes in the future. The recent decision from the Norwegian government to exempt offshore support vessels calling at Norwegian ports from paying carbon tax if their propulsion is powered by gas supports these considerations.

\subsection{Determination of the ship's main dimensions}

In the case of this work, the main dimensions and coefficients of the ship are influenced by the fuel cell system installed on board. The purpose of this study is not only to install fuel cells on board a certain ship but to integrate the system together with the rest of the systems and equipment in the vessel, obtaining a more sophisticated design. As stated before, the main task of a PSV is to carry supplies so it is imperative to integrate the system without reducing the spaces left for carrying cargo.

In order to obtain the main dimensions of the ship a database of similar ships already built must be prepared. An initial database is considered, composed of 50 ships selected according different standards:

- Vessel's main task: Platform Supply Vessel (PSV) or Anchor Handling Tug Supply (AHTS).

- Cargo capacity.

- Deadweight.

- Fuel tank capacity.

- Sailing speed.

The database includes the following data: length overall $L_{O A}$ length between perpendiculars $L_{p p}$, beam $B$, depth $D$, draft $T$, deadweight $D W T$, sailing speed $V$, main deck area $A$, fuel tank capacity $V_{T K}$, type of vessel and type of dynamic positioning $D P$. Dimensions are represented in Fig. 1. This initial database is later filtered to 15 ships, shown in Appendix, with the purpose of obtaining a more homogenous list of vessel's characteristics.

Once the database is already developed, linear regressions are made to obtain the main dimensions and coefficients of the ship. This step is done several times so as to refine the dimensions making sure they are correct. The main dimensions of a PSV are usually limited by operational considerations or by its zone of operations, therefore linear regressions sometimes have to be considered as a first approximation [19]. Besides, this work aims to develop an economic mode of operation (later defined in Table 5, Section 4.2, as ECO-Speed) where the amount of electrical power delivered by the fuel cell system covers up to $20 \%$ of the vessel's needs. To achieve this goal the hull of the vessel must be hydro dynamically optimized. As a result some of the dimensions obtained from linear regression have been modified to comply with the statements mentioned above. These are: length between perpendiculars $L_{p p}$, beam $B$ and depth $D$.

\subsubsection{Length between perpendiculars}

To carry out an estimation of the length of the ship, two different linear regressions have been done: one relates to the length of the ships with its deadweight (Regression I) and one relates to the length of the ships with its speed (Regression II). In [20] the length between perpendiculars is proposed to be a function of the cube root of the deadweight $L_{p p}=f(\sqrt[3]{D W T})$ whereas in [19] the length between perpendiculars is taken as a function of the sailing speed $V, L_{p p}=f(V)$.

\subsubsection{Beam}

As described in [19], there are two possibilities to estimate the beam of the ship. One is to use the beam as a function of the length between perpendiculars obtained in previous paragraphs (Regression I), $B=f\left(L_{p p}\right)$, and the other option is to set the beam as a function of the deadweight of the ships (Regression II), $B=f(D W T)$.

\subsubsection{Depth}

To estimate the depth, as well as in other dimensions, there are two possibilities. One is to use the length between perpendiculars $D=f\left(L_{p p}\right)$ (Regression I), while the other alternative is to relate the depth with the deadweight of the ship, $D=f(D W T)$ (Regression II), as has been already done when studying the beam.

\subsection{Electric evaluation of the consumers on board the ship}

A significant aspect of the Balmat design is related to the management of the electric needs on board the vessel. A detailed study of all the electric consumers on board the ship has been carried out in order to know their electric power needs depending on the mode in which the vessel is operating at a certain time. For each mode of operation, the following equation is applied to every electric consumer [21]: 
$P_{e}=P_{e c} \cdot K_{u}=P_{e c} \cdot K_{n} \cdot K_{s r}$

where $P_{e}$ is the electric evaluation power of the consumer; $P_{e c}$ stands for the power of the electric consumer; $K_{u}$ is defined as an utilization coefficient, $K_{u}=K_{n} \cdot K_{s r}$, being $K_{n}$ the simultaneity coefficient (ranging from 0.66 to 1 ), used when a certain consumer has redundancy, and $K_{s r}$ an operating range coefficient which takes values from 0 to 1 , depending on the extent of the consumer use. This $K_{s r}$ indicates the probabilistic of a certain consumer working at its maximum range for a certain mode of operation. The sum of $P_{e}$ from all of the electric consumers on each mode of operation gives the total electric power need supplied by the electric power plant. Once this step has been accomplished it is possible to search for the ideal number of diesel generators (gensets) to cover all the needs in every mode of operation.

\subsection{Heating needs: the boiler}

Among the different needs on board, the vessel has a notable demand of hot water that will be provided by means of a composite boiler. This kind of boiler can work burning fuel, but it is also able to work either using the high temperature exhaust gas from the diesel generators or, in this case, the SOFC fuel cells. The composite boiler will provide hot water for various services among which are hot water for accommodation, hot water for central heating, hot water for fresh water generation and hot water for washing tanks as is schematically represented in Fig. 2. An estimation of the thermal power required by these services has been made in each case [22-24].

\subsubsection{Hot water for accommodation}

Assuming that water consumption is $C_{1}=100 \mathrm{~L} / \mathrm{pax} /$ day and taking the maximum consumption as $C_{\max }=4 C_{1} n_{p a x}$, being $n_{p a x}$ the number of persons on board, the thermal power required to raise the temperature of fresh water from about $T_{\text {in }}=15^{\circ} \mathrm{C}$ to $T_{\text {out }}=50^{\circ} \mathrm{C}$, can be estimated from $\dot{Q} \simeq \rho_{w} C_{\max } c_{w}\left(T_{\text {out }}-T_{\text {in }}\right)$. Average density $\rho_{w}$ and specific thermal capacity $c_{w}$ of water have been used.

\subsubsection{Hot water for central heating}

A simplified model is devised to estimate the thermal power required to heat the air circulating inside the diverse rooms on board.
In this case $C_{\max }=\sum_{i} V_{i} \cdot N_{R_{i}}$, where $V_{i}$ is the volume of room $i$ and $N_{R_{i}}$ represent the number of air renovations per hour established for it. Assuming an average increment of $6 \mathrm{~K}$ from return to grille temperatures of the air, the thermal power required can be obtained as $\dot{Q} \simeq \rho_{a} C_{\max } c_{p_{a}}\left(T_{\text {grille }}-T_{\text {return }}\right)$. Average density $\rho_{a}$ and specific thermal capacity $c_{p_{a}}$ of air have been used.

\subsubsection{Hot water for fresh water generation}

Calculations are made to satisfy a fresh water demand of $8000 \mathrm{~kg} /$ day. This mass flow rate will be obtained by condensing the same vapour flow rate generated at a vacuum pressure $p$, which has been taken about $5 \mathrm{kPa}$. The sea water stream is assumed to enter the system about $5{ }^{\circ} \mathrm{C}$ under the saturation temperature of the working pressure $T_{\text {sat }}(p)$.

\subsubsection{Hot water for washing tanks}

In this case, a given mass $m_{s w}$ of sea water must be heated in a period of time $\tau$ to accomplish tanks washing operations. Here, a water temperature increase $\left(T_{\text {out }}-T_{\text {in }}\right)$ of $40^{\circ} \mathrm{C}$ in a time interval of $8 \mathrm{~h}$ is considered adequate and the heat power required can be estimated as $\dot{Q} \simeq m_{s w} c_{s w}\left(T_{\text {out }}-T_{\text {in }}\right) / \tau$. Average sea water specific thermal capacity $c_{s w}$ has been used.

\section{Fuel cell system on board}

Two methanol-fed $250 \mathrm{~kW}$ SOFC units are proposed to be installed on board the Balmat PSV designed. It was decided to choose methanol-fed SOFC, not only because it is a high temperature fuel cell with cogeneration capacity [25] but also because methanol is a sustainable product as it is the result of three specific chemical characteristics [26,27]:

- Methanol comprises the methyl and hydroxyl groups, which are very abundant and almost omnipresent.

- Methanol has a simple chemical structure and is rapidly synthesised from a range of carbon-containing materials, although production of some of these materials is more costly than others, as in the case of natural gas.

- Methanol is a fundamental block for a wide range of useful materials: fuels, glues, plastics, solvents, anti-freeze and others.

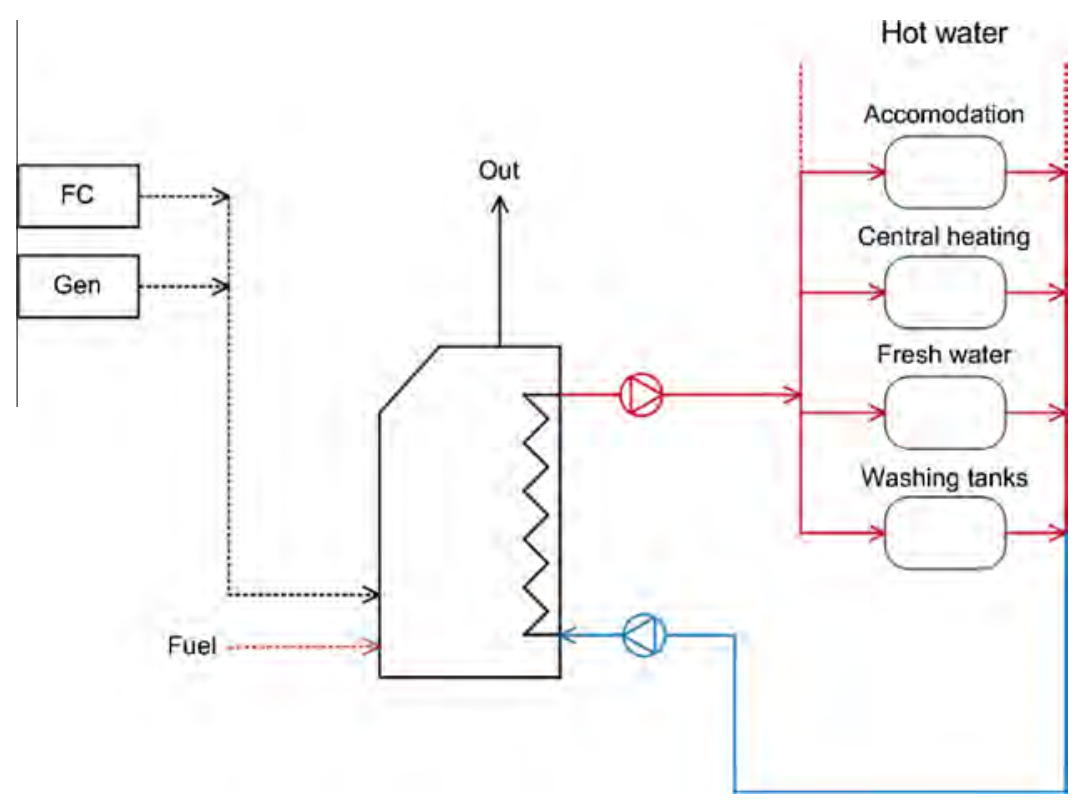

Fig. 2. Schematic representation of composite boiler functions on board. 
It is very important to emphasise that from an environmental perspective, in small quantities and at low concentrations, methanol is a naturally occurring material [26]. Methanol, or to be more precise, biomethanol, can be produced from natural materials, even more easily and efficiently than ethanol (the next largest molecule of alcohol), and also from cheaper and non-food raw materials such as biomass.

Then, it would be interesting the use of methanol as a marine fuel [15]. Furthermore, although methanol has a low flammability limit and it is toxic when inhaled or ingested and when it comes into contact with skin, the interest for methanol as fuel in marine applications has significantly increased in recent years. This has made the 1st July 2013 Det Norske Veritas submitted the first regulation for low flashpoint liquid fuelled ship installations [28]. The new rules cover issues of materials, arrangement, design, fire safety, electrical systems, control, monitoring, safety systems, engines, pumps, manufacture, testing and personal protection. The Balmat vessel meets the requirements for LFL (low flashpoint liquid) according to this regulation.

\subsection{On board installation}

The vessel will house two $250 \mathrm{~kW}$ modules of methanol-fed SOFC fuel cells that would be installed in a dedicated space [17] called Fuel Cell Room. Characteristics and arrangement of these modules are based on information extracted from data published in [25,29-31], which are related to the previously cited Methapu project [15]. The system main dimensions have been defined taking as a basis data provided in $[27,29,32]$. The claimed basic characteristics of the SOFC system performance are summarized in Table 1 and a simplified flow sheet of a possible configuration is schematized in Fig. 3.

Liquid methanol enters the system and after being treated, it is introduced into the fuel processor FP $[27,30,32]$ to obtain a hydrogen-rich gas mixture (syn gas) which is later heated and conducted towards the anode. At the same time atmospheric air is heated and conducted towards the cathode. Air is supplied to the cathode via a fan, and is pre-heated in a heat exchanger before entering the cell. The result, as has been mentioned, will be electricity, but the surplus hydrogen is partially re-used and partially burned off in the catalytic burner to assist the reforming process in the FP and to prevent an atmosphere containing an excess of hydrogen, as it is an inflammable gas. Taking as a basis the conceptual design of a $250 \mathrm{~kW}$ SOFC system described in [29] fed by natural gas, it has been assumed that the system will be housed in an ISO standard container with the dimensions $5.8 \mathrm{~m} \times 2.3 \mathrm{~m} \times 2.3 \mathrm{~m}$, being $12,350 \mathrm{~kg}$ the estimated weight. It has been assumed also that the system includes the elements listed in Table 2 and is divided into three temperature zones, clearly differentiated in Fig. 4. These are:

- A high temperature zone $(750-850)^{\circ} \mathrm{C}$, where the fuel cell stack (1) and the cell entry air pre-heater (4) are found.

- An intermediate temperature zone $(350-550){ }^{\circ} \mathrm{C}$, where the fuel processor (2), the heat exchangers (3) and (7), and the catalytic burner (5) are located.

Table 1

Characteristics of the SOFC system proposed to be installed on board (Based on [27]).

\begin{tabular}{ll} 
Nominal electrical power output (kW) & 250 \\
Electric efficiency (\%) & 47 \\
Total efficiency (\%) & $80-85$ \\
Voltage (Vac/Hz) & $400 / 50$ \\
Fuel & Methanol \\
\hline
\end{tabular}

- A low temperature zone, where the control systems and electronics are placed, together with other Balance of Plant components $(6,8-11)$.

\subsection{Fuel system}

Regarding the fuel cells, the main fuel system tanks are the methanol storage tanks. The vessel is fitted with two storage tanks, the capacity of which is calculated here, and for which the consumption of methanol must be known. As $250 \mathrm{~kW}$ methanol-fed SOFC modules are not yet commercialized and this work is at the conceptual design stage, such consumption is thus estimated by using the available information in [32], Tables 1 and 2, where various hybrid SOFCgas turbine systems, SOFC-GT systems, are modelled. Configurations with methanol-fed SOFC have been taken into account.

\subsubsection{FC Fuel Consumption}

Directly related with the fuel consumption of the fuel cell, i.e., FC Fuel Consumption, defined as the mass of fuel required per unit of energy generated, are the total fuel mass flow rate $\dot{m}_{f}$ and power $\dot{W}_{F C}$ of the system:

FC Fuel Consumption $=\frac{\dot{m}_{f}}{\dot{W}_{F C}}$

\subsubsection{Total fuel tank capacity}

To calculate the total fuel tank capacity $V_{T K}$, FC Fuel Consumption, power $\dot{W}_{F C}$, and autonomous operation time $t$, in addition to the fuel density $\rho_{f}$, must be known:

$V_{T K}=\frac{\dot{m}_{f} \cdot t}{\rho_{f}}=\frac{\text { FC Fuel Consumption } \cdot \dot{W}_{F C} \cdot t}{\rho_{f}}$

Autonomy of 21 days has been considered adequate for this vessel when operating with fuel cells. As said, to estimate the total fuel mass flow rate $\dot{m}_{f}=$ FC Fuel Consumption $\cdot \dot{W}_{\mathrm{FC}}$ required by each $250 \mathrm{~kW}$ SOFC system installed on board the Balmat vessel, data from Tables 1 and 2 reported in [32] have been used. Estimation of FC Fuel Consumption has been carried out taking as basis layouts TSOFC-IR and PSOFC-IR represented in Fig. 1 of such reference. These layouts correspond to modelled tubular (TSOFC-IR) and planar (PSOFC-IR) SOFC hybridized with gas turbines (GT). Both configurations are placing the fuel processor inside the recycle loop, similarly to that shown in Fig. 3 of this work.

Given that the total power output of methanol for the hybrid SOFC-GT systems is known [32], the output power corresponding to the SOFC system $\dot{W}_{F C}$ can be obtained. As the whole system power output is $\dot{W}_{\text {sist }}=500 \mathrm{~kW}$ being $\dot{W}_{\text {sist }}=\dot{W}_{G T}+\dot{W}_{F C}$ the fuel cell power output will be $\dot{W}_{F C}=\dot{W}_{\text {sist }}-\dot{W}_{G T}$. The power delivered by the GT can be estimated as the difference between the turbine power output and the compressor power consumption as $\dot{W}_{G T} \simeq \dot{m}_{a} c_{p_{a}}\left\{\eta_{T} T_{3}\left[1-r_{p}^{\frac{1-\gamma}{\gamma}}\right]-\frac{T_{1}}{\eta_{C}}\left[r_{p}^{\frac{\gamma-1}{\gamma}}-1\right]\right\}$, where the compressor pressure ratio is represented by $r_{p}$, the compressor inlet temperature by $T_{1}$, and $\dot{m}_{a}$ and $T_{3}$ stand for the air mass flow rate and the turbine inlet temperature, respectively. Efficiencies of turbine and compressor units are represented by $\eta_{T}$ and $\eta_{C}$, respectively.

As summarized in Tables 1 and 2 [32], TSOFC-IR layout works with the operating parameters $r_{p}=4, \dot{m}_{a}=0.97 \mathrm{~kg} \mathrm{~s}^{-1}$ and $T_{3}=$ $1191 \mathrm{~K}$, whereas PSOFC-IR operates with $r_{p}=6, \dot{m}_{a}=1.07 \mathrm{~kg} \mathrm{~s}^{-1}$ and $T_{3}=1171 \mathrm{~K}$. In both cases $T_{1}=298 \mathrm{~K}, \eta_{T}=0.85$ and $\eta_{C}=0.80$. Then, $\dot{W}_{G T}=146.3 \mathrm{~kW}$ and $\dot{W}_{F C}=353.7 \mathrm{~kW}$ for TSOFC-IR layout and $\dot{W}_{G T}=161.1 \mathrm{~kW}$ and $\dot{W}_{F C}=338.9 \mathrm{~kW}$ for TSOFC-IR. As the total methanol mass flow rate for PSOFC-IR and TSOFC-IR are reported as $40.7 \times 10^{-3} \mathrm{~kg} \mathrm{~s}^{-1}$ and $41.7 \times 10^{-3} \mathrm{~kg} \mathrm{~s}^{-1}$, respectively, the methanol mass flow rate per kilowatt generated by the SOFC, i.e., FC Fuel 


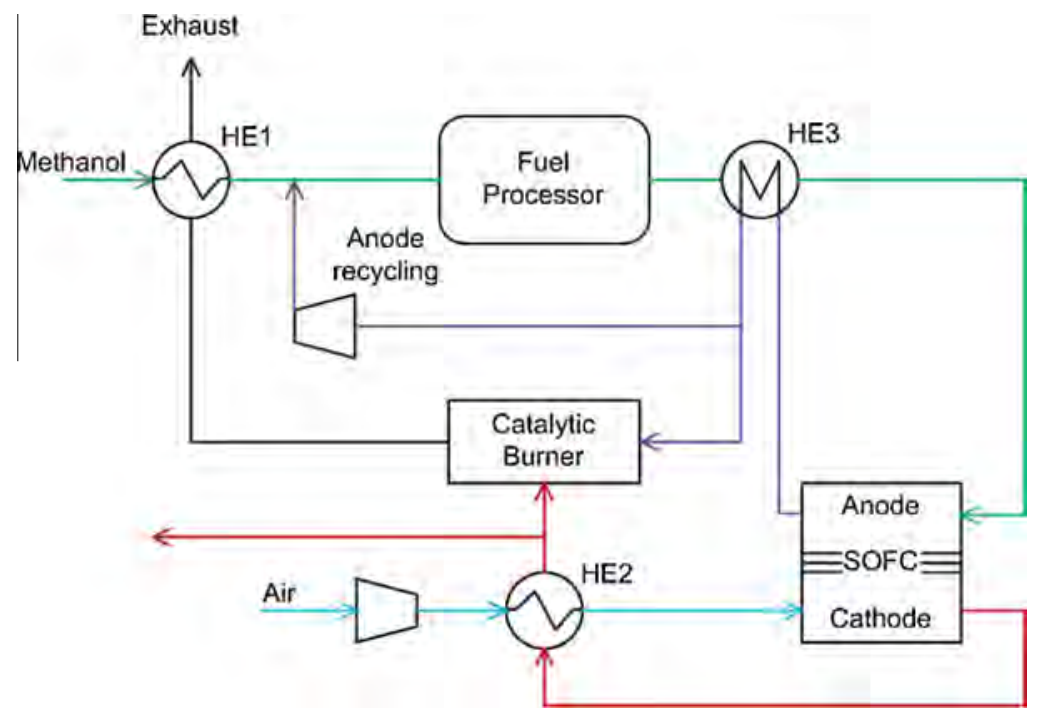

Fig. 3. Simplified flow sheet for the $250 \mathrm{~kW}$ Fuel Cell SOFC System. (Based on [27,29].)

Table 2

Main elements taking part of the SOFC system.

\begin{tabular}{|c|c|c|c|}
\hline $\begin{array}{l}\text { Identifier } \\
\text { element }\end{array}$ & Description & $\begin{array}{l}\text { Identifier } \\
\text { element }\end{array}$ & Description \\
\hline 1 & SOFC fuel cell stack & 7 & $\begin{array}{l}\text { Anode inlet syn gas } \\
\text { pre-heater (HE3) }\end{array}$ \\
\hline 2 & Fuel processor & 8 & Air fan \\
\hline 3 & Fuel conditioner (HE1) & 9 & Control unit \\
\hline 4 & $\begin{array}{l}\text { Fuel cell inlet air pre-heater } \\
\text { (HE2) }\end{array}$ & 10 & $\begin{array}{l}\text { Power conversion } \\
\text { unit }\end{array}$ \\
\hline 5 & Catalytic burner & 11 & $\begin{array}{l}\text { Back-up power } \\
\text { unit }\end{array}$ \\
\hline 6 & Heat recovery unit & & \\
\hline
\end{tabular}

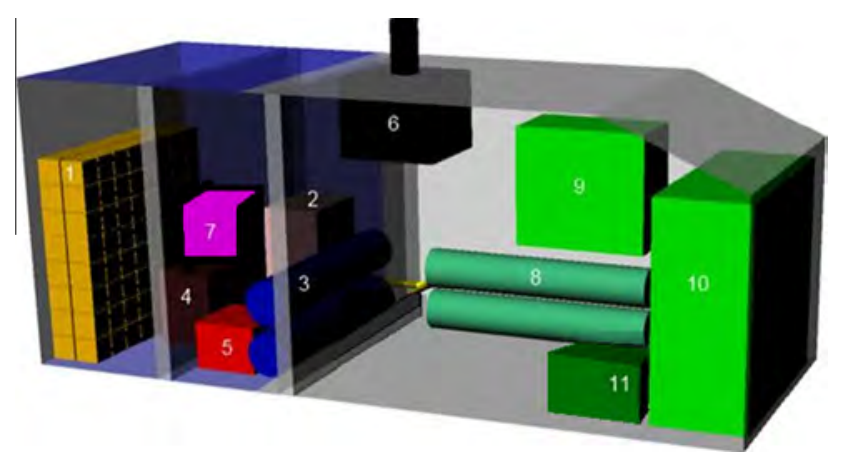

Fig. 4. 3D model of the packaging configuration proposed for the $250 \mathrm{~kW}$ SOFC module to be installed on board.

Consumption, results in $1.15 \times 10^{-4} \mathrm{~kg} \mathrm{~s}^{-1} \mathrm{~kW}^{-1}$ and $1.23 \times 10^{-4}$ $\mathrm{kg} \mathrm{s}^{-1} \mathrm{~kW}^{-1}$, respectively.

Thus, the FC Fuel Consumption, $\frac{\dot{m}_{f}}{\dot{W}_{f f}}$, of the methanol-fed SOFC system has been estimated as $1.2 \times 10^{-4} \mathrm{~kg} \mathrm{~s}^{-1} \mathrm{~kW}^{-1}$. A similar result can be derived from [30]. Thus, it has been possible to estimate the total methanol mass flow rate $\dot{m}_{f}$ and the total fuel tank capacity $V_{T K}$ to operate the $250 \mathrm{~kW}$ SOFC modules installed in Balmat.

\subsection{Heat recovery}

The high operating temperature of the SOFC fuel cells offer the possibility of using the residual heat via cogeneration. As stated before, while the two fuel cell systems in the Balmat vessel remain in operation they generate $500 \mathrm{~kW}(2 \times 250 \mathrm{~kW})$ of total power.
Estimation of the heat that could be obtained through cogeneration has been made taking again as a basis the data given in [32], Tables 1 and 2, for PSOFC-IR and TSOFC-IR hybrid systems. The heat released by the fuel cell during the SOFC-GT hybrid system operation can be estimated as the heat received by the GT air flow between the compressor outlet at $T_{2}$ and the turbine inlet at $T_{3}$ by $\dot{Q}_{\operatorname{cog} F C} \simeq \dot{m}_{a} \bar{c}_{p}\left(T_{3}-T_{2}\right)$, being $T_{2}=T_{1}\left[1+\left(r_{p}^{\gamma-1}-1\right) / \eta_{C}\right]$. In this case, the average specific thermal capacity value has been assumed as $1.107 \mathrm{~kJ} \mathrm{~kg}^{-1} \mathrm{~K}^{-1}$. For TSOFC-IR layout, $T_{2}=479 \mathrm{~K}$ and $\dot{Q}_{\operatorname{cog} F C}=766.6 \mathrm{~kW}$. In the case of PSOFC-IR layout, $T_{2}=547 \mathrm{~K}$ and $\dot{Q}_{\operatorname{cog} F C}=741.1 \mathrm{~kW}$. Therefore the $\dot{Q}_{\operatorname{cog} F C} / \dot{W}_{F C}$ ratio results in 2.17 and 2.19 , respectively. Thus, for the methanol-fed SOFC system such ratio has been estimated as 2.2 .

Taking these results as a basis, the heat generated from a $250 \mathrm{~kW}$ methanol-fed SOFC to be used through cogeneration has been estimated.

\section{Results}

\subsection{Ship's main dimensions}

The results obtained according to the procedures explained in Section 2.2 can be seen in Table 3, where the final dimensions of the vessel designed are also shown.

If the results are compared with the lengths between perpendiculars $L_{p p}$ of the ships included in the final database used, see Appendix, it is noticeable that $79.73 \mathrm{~m}$ is too long while $74.60 \mathrm{~m}$ is more in accordance with the $L_{p p}$ value of other ships. Nevertheless the length of the ship has to be enlarged so as to fit the fuel cell system on board, thus the final length of the ship is $77.40 \mathrm{~m}$. Aiming towards finding more slender hull shapes, the beam chosen for the Balmat design will be $17.00 \mathrm{~m}$. Once the other dimensions are already known and keeping in mind the target of developing a slenderer hull shape the depth of the ship has been taken as $7.20 \mathrm{~m}$. From these dimensions a hydro dynamically optimized hull design has been developed.

\subsection{Electric balance and ECO-Speed results}

The results of Eq. (1) have been taken as a basis to choose the installation of four $2400 \mathrm{kV} \mathrm{A} \mathrm{MaK}$ gensets [33], one of them being a spare unit. Table 4 shows the operating range of the 
diesel gensets installed on board the ship, in the Engine Room, depending on the mode of operation. The optimum operating range of most marine diesel engines comprises $70-95 \%$ of its Maximum Continuous Revolution (MCR). Running the gensets outside this range would result in damages to the units. A diesel engine running at ranges above $95 \%$ would cause breakdowns and notably reduce the life of the engine. Besides fuel consumptions would increase dramatically. On the other side, a diesel engine running at low ranges (below 70\%) does not work efficiently as the fuel inside the cylinders does not burn adequately and thus the interior of the engine gets dirty with combustion particles. This causes more maintenance on the diesel generators and also higher fuel consumption [34].

The so called ECO-Speed mode of operation portrayed in Table 4, for sailing alongside offshore installations at velocities of 7-8 knots (about 13-15 $\mathrm{km} \mathrm{h}^{-1}$ ), does not show the impact of the fuel cell system in this mode. Instead, the mode of operation is covered by means of only one diesel generator. Therefore, the operating range shown in Table 4, as has been stated before, is too high. Instead, the solution suggested in this work is to take advantage of the electric energy generated by the fuel cells to sail with only one diesel generator, as shown in Table 5, allowing the vessel to save fuel and thus to reduce atmosphere pollutant gases. In this table the power needs and power output of the fuel cells are expressed in $\mathrm{kV} \mathrm{A}$ where a power factor 0.80 has been used.

The combined use of the diesel generator and the fuel cells fully covers the vessel's electrical needs in this electric load situation, maintaining a fine operating range for the generators. At this mode of operation the performance of the vessel is limited as some secondary systems of the ship are switched off and the main consumers, the azimuth thrusters, operate at about $50 \%$ of its performance in order to reduce electric power consumption. However, most of the systems and equipment on board the vessel that work at $400 \mathrm{~V} / 50 \mathrm{~Hz}$ are fed by the fuel cells.

\subsection{Heating needs results: the boiler}

Based on the studies carried out in Section 2.4 it is estimated that $440 \mathrm{~kW}$ of thermal power are needed for hot water production. This thermal power appears as a result of the summation of $30,97,232$ and $63 \mathrm{~kW}$ corresponding to the requirements for hot water for accommodation, hot water for central heating, hot water for fresh water generation and hot water for washing tanks, respectively. Boiler efficiency of $97 \%$ has been assumed.

As specified, the composite boiler generates the hot water required on board by burning fuel or it can take advantage of the exhaust gas emissions from the diesel generators or the SOFC fuel cells to heat up the water. This highly improves the operational flexibility of the vessel as she will be able to cover her hot water demands by three different methods. In general, depending on the heat power requirements of a given vessel, different combinations of these methods will appear as adequate. Using the cogeneration heat from the SOFC fuel cell system will also decrease the amount of fuel consumed on board and thus reduce the exhaust gas emissions.

Table 3

Dimensions of the Balmat vessel.

\begin{tabular}{llll}
\hline Dimensions & \multicolumn{2}{l}{ Regressions } & \multirow{2}{*}{ Final dimensions } \\
\cline { 2 - 3 } & Regression I & Regression II & \\
\hline Length (m) & 79.73 & 74.60 & 77.40 \\
Beam (m) & 18.07 & 18.26 & 17.00 \\
Depth (m) & 7.56 & 7.58 & 7.20 \\
\hline
\end{tabular}

\section{4. fuel cell system results}

As said, three weeks autonomy has been chosen for the vessel when operating with the fuel cells modules. Calculations made for one $250 \mathrm{~kW}$ SOFC system lead to the results collected in Table 6.

Therefore, as two $250 \mathrm{~kW}$ methanol-fed SOFC are installed, two tanks of $68 \mathrm{~m}^{3}$, that is, fuel tanks with $136 \mathrm{~m}^{3}$ total capacity are installed and $1100 \mathrm{~kW}$ could be obtained through cogeneration. Thus if the fuel cells are working, the heat recovery obtained via cogeneration can replace the fuel consumption of the boiler according to the data provided in Section 4.3 and corroborated by the data given in [31].

\subsection{Integration of the fuel cell system}

The Balmat platform supply vessel is a ship designed to successfully accomplish an enormous variety of tasks. The ship is driven by a quad MaK 6M25 electric drive located inside the Engine Room, each one developing $2400 \mathrm{kV} \mathrm{A}$ whilst turning at $750 \mathrm{rpm}$ [33]. These main generators consume Marine Diesel Oil (MDO) and have an output voltage of $6.6 \mathrm{kV}$ (a.c.) while the consumers of the ship work at different voltages that are altered using transformers:

- Main thrusters: $690 \mathrm{~V} / 50 \mathrm{~Hz}$.

- Main consumers: $400 \mathrm{~V} / 50 \mathrm{~Hz}$

- Illumination consumers: $230 \mathrm{~V} / 50 \mathrm{~Hz}$.

The main task of the diesel generators is to supply electricity to the ship's propellers, which are shown in Fig. 5. The desired thrust is set via the speed of the electric motor. That allows the generators to always run at the optimum operating point and therefore to reduce fuel consumption.

The power plant is completed by a set of two $250 \mathrm{~kW}$ Solid Oxide Fuel Cells (SOFC) fed with methanol located in the Fuel Cell Room, as depicted in Fig. 6. Due to the voltage characteristics and requirements, they (Table 1 ) will only supply electric energy to the main consumers but not to the thrusters units.

Disposition of the Fuel Cell Room, astern of the Engine Room is represented in Fig. 7. The Engine Room has a length of $17.4 \mathrm{~m}$ (from frame 68 to frame 106) and takes up two floors, from the tank top to the tween deck ( $6.2 \mathrm{~m}$ high). The Fuel Cell Room has a length of $5.4 \mathrm{~m}$ (from frame 68 to frame 77 ) and it is placed in the tween deck.

Therefore, the vessel has a diesel-electric power plant composed of four generators (one of them being a spare engine) and two fuel cells, which cover all the ship's electrical needs, in every mode of operation, as shown in Tables 4 and 5.

\subsection{Legislation and environmental results}

The main MaK 6M25 C diesel generators fitted on board the Balmat comply with all of the MARPOL pollution requirements and regulations, as established in [1]. On the other hand the total amount of exhaust mass gas flow produced by one diesel generator is about $10,904.5 \mathrm{~kg} / \mathrm{h}$, as specified in [33]. This exhaust gas is typically formed by a mixture of elements in different concentrations, as can be seen in Fig. 8.

Among the (1\%) pollutants, PM (Particle Matter), $\mathrm{CO}, \mathrm{C}_{x} \mathrm{H}_{y}$ and $\mathrm{SO}_{2}$ can be found. Therefore, the exhaust gas flow produced by the vessel depends on her mode of operation, as can be shown in Table 7.

Then, sailing at ECO-Speed gives the advantage, among others, of emitting less exhaust gases as the ship is operating with only one diesel generator. 
Table 4

Operating range of the diesel generators depending on the mode of operation.

\begin{tabular}{lrlll}
\hline $\begin{array}{l}\text { Mode of operation } \\
(\mathrm{kV} \mathrm{A})\end{array}$ & $\begin{array}{l}\mathrm{N}^{\circ} \\
\text { genset }\end{array}$ & $\begin{array}{l}\text { Generator power output } \\
(\mathrm{kV} \mathrm{A})\end{array}$ & $\begin{array}{l}\text { Range } \\
(\%)\end{array}$ \\
\hline Normal & 4368 & 2 & 4800 & 91 \\
Fire fighting & 5760 & 3 & 7200 & 80 \\
Manoeuvring & 5472 & 3 & 7200 & 76 \\
Platform operations & 6624 & 3 & 7200 & 92 \\
ECO-Speed & 2352 & 1 & 2400 & 98 \\
Emergency $^{\mathrm{a}}$ & 180 & 1 & 240 & 75 \\
\hline
\end{tabular}

a The ship relies on an emergency generator for emergencies. This generator has a power output of $240 \mathrm{kV} \mathrm{A}$.

Table 5

Operating range of the diesel generator and the fuel cells under ECO-Speed.

\begin{tabular}{clccl}
\hline & & $\begin{array}{l}\text { Power output } \\
(\mathrm{kVA})\end{array}$ & $\begin{array}{l}\text { Power needs } \\
(\mathrm{kVA})\end{array}$ & $\begin{array}{l}\text { Range } \\
(\%)\end{array}$ \\
\hline \multirow{2}{*}{$\begin{array}{c}\text { ECO- } \\
\text { Speed }\end{array}$} & $\begin{array}{l}\text { Fuel Cells } \\
\text { Diesel } \\
\text { generator }\end{array}$ & 625 & 480 & 77 \\
& 2400 & 1869 & 78 \\
\hline
\end{tabular}

Table 6

Some characteristics of the $250 \mathrm{~kW}$ SOFC module to be installed on board the Balmat vessel based on 21 autonomy days.

$\begin{array}{ll}\text { FC Fuel Consumption, } \dot{m}_{f} / \dot{W}_{F C}\left(\mathrm{~kg} \mathrm{~s}^{-1} \mathrm{~kW}^{-1}\right) & 1.2 \times 10^{-4} \\ \text { FC Fuel Consumption }\left(\mathrm{kg} \mathrm{kW} \mathrm{h}^{-1}\right) & 0.43 \\ \text { Total fuel tank capacity, } V_{T K}\left(\mathrm{~m}^{3}\right) & 68 \\ \text { Total fuel mass flow rate }\left(\mathrm{kg} \mathrm{s}^{-1}\right) & 3 \times 10^{-2} \\ \text { Heat power via cogeneration, } \dot{Q}_{\operatorname{cog} F C}(\mathrm{~kW}) & 550\end{array}$

\section{Cost estimation}

Finally, to study the cost advantage of operating with the diesel-fuel cells hybrid system, a preliminary cost estimation regarding the fuel consumed and the initial investment in the propulsion plant has been performed. More detailed studies on economic viability of hybrid systems involving fuel cells integration $[35,36]$ go far beyond the scope of this work.

\subsection{Fuel costs}

Savings of fuel cost achieved with the use of methanol-fed SOFC in Balmat vessel propulsion are firstly evaluated. With this purpose, the costs of the fuel used during 21 shipping days around the offshore platforms under two operating modes are compared. Normal operating mode, with two diesel generators, and ECOSpeed, with one diesel generator and two methanol-fed SOFC modules (see Table 4) have been studied. As derived from the total fuel cost shown in Table 8 for the two operating modes, savings of $90,586.58 €$ are produced every 21 days when the methanol-fed SOFC are used.

\subsection{Initial investment}

Next, the propulsion plant cost of a vessel operating in the offshore platforms integrated by four diesel generators is compared with that of Balmat, consisting of four diesel generators and two SOFC systems. Taking as a basis marine industry information, the propulsion plant cost of a conventional PSV can be estimated about $2,000,000.00 €$ whereas the Balmat propulsion plant cost has been estimated in $2,804,500.00 €$. Such cost estimate is derived from data available in [27] from which the average value for pessimistic

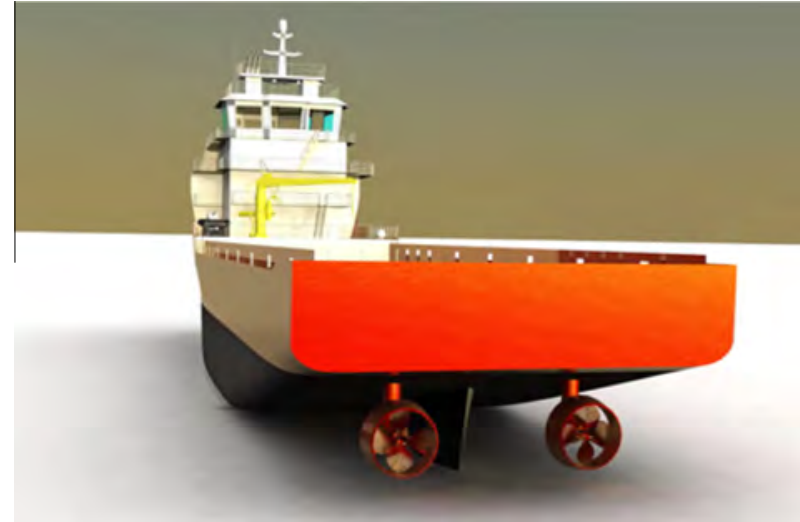

Fig. 5. Azimuth propellers of the Balmat design.

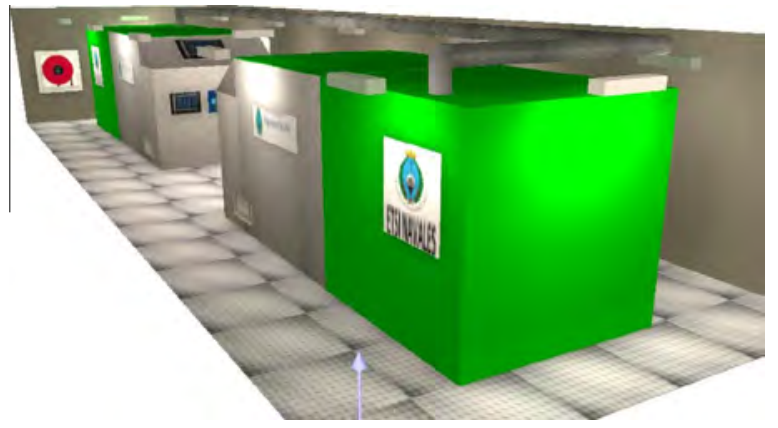

Fig. 6. 3D Fuel Cell Room on board the Balmat design.

and optimistic investment cost assumption (1609 $€ \mathrm{~kW}^{-1}$, year 2013) for the SOFC power plant has been calculated. Therefore, the two $250 \mathrm{~kW}$ SOFC modules will originate an initial extra cost of $804,500.00 €$.

As a first approximation, such initial extra cost would be recovered after nine navigation periods of 21 days within the offshore platforms. It must be taken into account that there is still much uncertainty about the actual commercial cost achievable by SOFC systems [30], but it can be expected this cost to be lower in the future as technology is more mature. Therefore, from an economic point of view, the hybrid diesel generator-SOFC power plant proposed in Balmat appears as an advantageous option in marine applications.

\section{Conclusions}

This work illustrates the conceptual design of a large surface vessel, a platform supply vessel which has been called Balmat, with an innovative hybrid diesel electric-fuel cell driven propulsion. The fuel chosen to operate the fuel cells is methanol, a liquid fuel with potential interest in marine applications. To carry out the integration of fuel cells within the ship major changes and improvements have been made. To maintain the spaces left for carrying cargo the main dimensions of the ship, and therefore, her hull has been redesigned obtaining more slender hull shapes. The Engine Room arrangement has been also redesigned in order to fit the fuel cell modules located in the Fuel Cell Room. A detailed study of all the electric consumers on board the ship has been carried out in order to know the electric power needs of the ship in every mode of operation and to determine the number of diesel engines (gensets) to be installed. Different heating needs of the vessel have been estimated, verifying that cogeneration heat obtained from the 


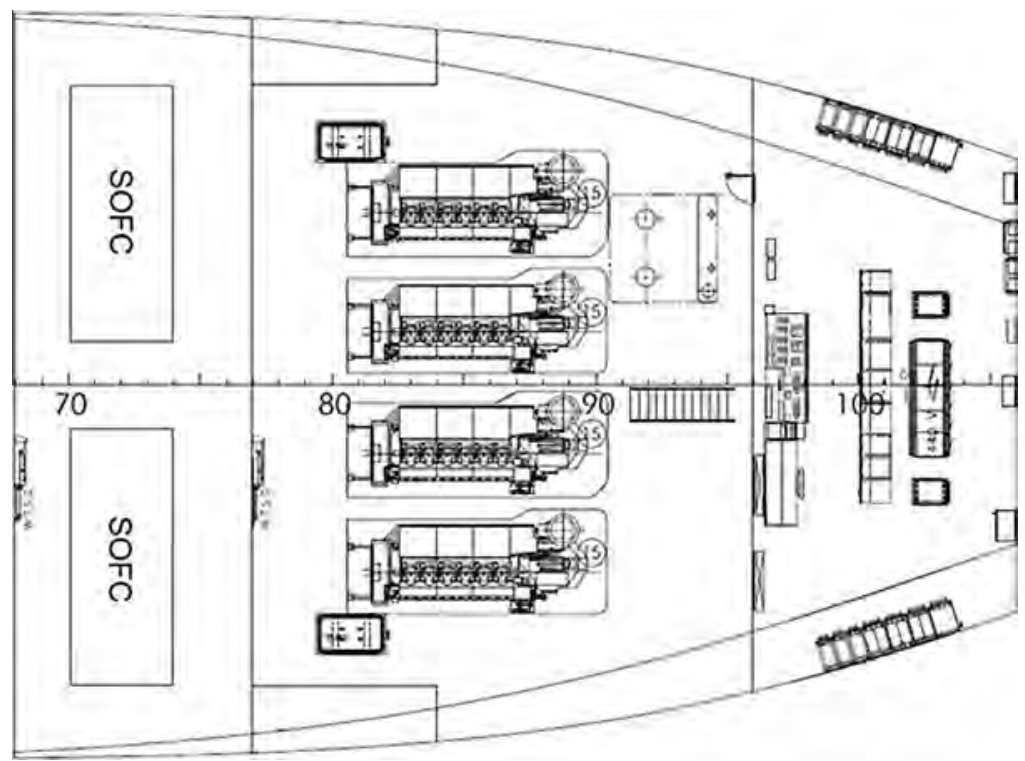

Fig. 7. Layout of the Fuel Cell Room and Engine Room of the Balmat design.

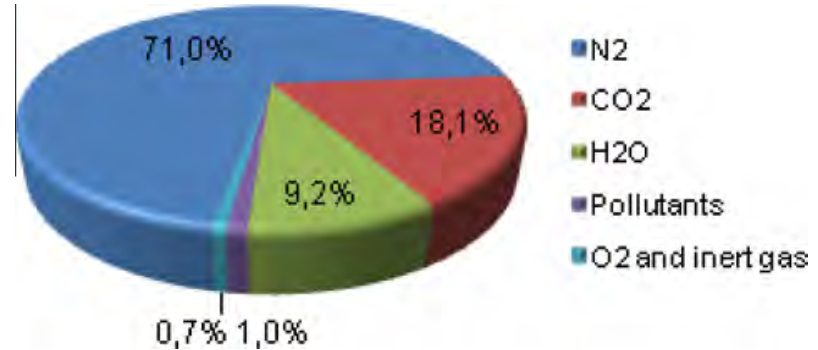

Fig. 8. Typical diesel engine emissions.

Table 7

Total exhaust mass gas flow produced by the vessel.

\begin{tabular}{lll}
\hline Mode of operation & Number of generators & Exhaust mass flow $(\mathrm{kg} / \mathrm{h})$ \\
\hline Normal & 2 & $21,809.0$ \\
Fire fighting & 3 & $32,713.7$ \\
Manoeuvring & 3 & $32,713.7$ \\
Platform ops. & 3 & $32,713.7$ \\
ECO-Speed & 1 & $10,904.5$ \\
\hline
\end{tabular}

Table 8

Fuel cost estimation of the Balmat vessel under two operating modes during 21 shipping days.

\begin{tabular}{llll}
\hline Mode of operation & Normal & ECO-Speed & \\
\hline Model & Mak 6M25 C & Mak 6M25 C & SOFC \\
Quantity & 2 & 1 & 2 \\
Power output $(\mathrm{kW})$ & 1980 & 1980 & 250 \\
Fuel & MDO & MDO & Methanol \\
Consumption $\left(\mathrm{kg} \mathrm{kW} \mathrm{h}^{-1}\right)$ & 0.184 & 0.184 & 0.430 \\
Fuel price $\left(€ \mathrm{~kg}^{-1}\right)$ & 0.71 & 0.71 & 0.37 \\
Sailing hours & 504 & 504 & 504 \\
Fuel consumed $(\mathrm{kg})$ & $367,234.56$ & $183,617.28$ & $108,360.00$ \\
Fuel costs $(€)$ & $261,570.84$ & $130,785.42$ & $40,198.84$ \\
Total fuel cost $(€)$ & $261,570.84$ & $170,984.26$ & \\
\hline
\end{tabular}

high-temperature SOFC fuel cells installed on board can satisfy such requirements by supplying the exhaust gases to the composite boiler on board. Tank's capacities, including that of methanol feeding the fuel cells, have been dimensioned. To develop this work, recent rules and regulations applicable to marine fuel cell installations have been taken into account. As a result, the power plant will be comprised of four diesel generators and a set of two SOFC fuel cell systems. Two $250 \mathrm{~kW}$ high-temperature SOFC systems using methanol as a fuel have been integrated within the ship and due to the voltage characteristics and requirements, they will only supply electric energy to the main consumers but not to the thrusters units. The new configuration proposed in this work provides the ship with an electric propulsion system that gives her a high manoeuvrability while in operation and a much lower fuel consumption, as well as less environmental impact by notably reducing pollutant emissions to the atmosphere, as she is able to sail inside an offshore platform park by means of the $500 \mathrm{~kW}$ power output generated by the fuel cells and only one diesel generator, designed as ECO-Speed mode of operation. In this case, up to $20 \%$ of the electrical power of the vessel's needs could be covered by the fuel cells.

It can be concluded that the Balmat conceptual design is an excellent example of how fuel cells can be successfully implanted on board commercial vessels without limiting their performance and operational capabilities. From the technical and economic points of view, the SOFC installation in Balmat presents viability for several reasons: fuel economy, reliability, operational flexibility, layout flexibility, lower emissions, noise and vibrations. It is essential for the future of fuel cells in the marine industry to keep on developing more advanced systems to meet the requirements on board ships so that ship owners will begin to trust this technology and thus implementing them on board their ships.

\section{Acknowledgments}

This work has been partially funded by the Spanish Ministerio de Ciencia e Innovación in the frame of the Project Code No. ENE2011-28735-C02-02. The authors gratefully acknowledge ETSI Navales (UPM) Library Staff for the help received.

\section{Appendix A.}

Database of ships used to calculate the dimensions of the Balmat vessel (see http://www.supplyvessel.net/). 


\begin{tabular}{llllllllrll}
\hline Ship & $L_{O A}(\mathrm{~m})$ & $L_{p p}(\mathrm{~m})$ & $B(\mathrm{~m})$ & $T(\mathrm{~m})$ & $D(\mathrm{~m})$ & $D W T(\mathrm{t})$ & $A\left(\mathrm{~m}^{2}\right)$ & $V_{T K}\left(\mathrm{~m}^{3}\right)$ & $V(\mathrm{kn})$ & $V(\mathrm{~km} / \mathrm{h})$ \\
\hline Aries Scout & 71.90 & 66.80 & 16.00 & 5.81 & 7.00 & 3184 & 693 & 1029 & 12.0 & 22.2 \\
Bourbon Crown & 80.00 & 69.30 & 18.00 & 6.60 & 8.00 & 2851 & 570 & 1150 & 15.0 & 27.8 \\
Bourbon Borgstein & 87.70 & 76.00 & 18.00 & 6.60 & 8.00 & 2850 & 542 & 1336 & 15.0 & 27.8 \\
BB Troll & 73.90 & 65.40 & 16.00 & 6.50 & 7.60 & 2881 & 550 & 853 & 12.0 & 22.2 \\
E.R. Narvik & 73.60 & 68.30 & 16.00 & 5.80 & 7.00 & 3240 & 720 & 980 & 14.5 & 26.9 \\
Uos Discovery & 76.50 & 67.40 & 17.50 & 5.50 & 8.00 & 3000 & 600 & 1111 & 17.0 & 31.5 \\
SOV Ullswater & 78.00 & 72.29 & 20.40 & 5.50 & 7.00 & 2737 & 700 & 845 & 11.0 & 20.4 \\
Uos Atlantis & 76.50 & 67.40 & 17.50 & 5.50 & 8.00 & 3000 & 600 & 1111 & 17.0 & 31.5 \\
Olympic Poseidon & 79.80 & 69.30 & 15.00 & 6.60 & 8.00 & 3550 & 640 & 1270 & 16.0 & 29.6 \\
Olympic Octupus & 78.30 & 68.20 & 17.20 & 6.30 & 8.30 & 2600 & 510 & 1000 & 18.0 & 33.3 \\
Olympic TBN & 79.60 & 72.00 & 16.40 & 6.20 & 7.45 & 3500 & 745 & 1210 & 12.0 & 22.2 \\
Olympic Progress & 73.60 & 68.30 & 16.00 & 5.85 & 7.00 & 3291 & 680 & 980 & 14.5 & 26.9 \\
Olympic Promoter & 73.60 & 68.30 & 16.00 & 5.85 & 7.00 & 3266 & 680 & 980 & 14.5 & 26.9 \\
Toisa Sentinel & 94.30 & 87.46 & 19.50 & 4.74 & 7.30 & 3025 & 775 & 1808 & 11.0 & 20.4 \\
Tor Viking II & 83.70 & 75.20 & 18.00 & 7.20 & 8.50 & 3000 & 603 & 1190 & 11.0 & 20.4 \\
\hline
\end{tabular}

\section{References}

[1] International Convention for the Prevention of Pollution from Ships (MARPOL 73/78. Annex VI). London: International Maritime Organization (IMO); 2011.

[2] International Maritime Organization (IMO). Special Areas under MARPOL; <http://www.imo.org/OurWork/Environment/PollutionPrevention/ SpecialAreasUnderMARPOL/Pages/Default.aspxI>.

[3] Ports of Rotterdam and Gothenburg in LNG alliance; <http:// www.portofrotterdam.com/en/News/pressreleases-news/Pages/portsrotterdam-gothenburg-lng-alliance.aspx>. (last accessed 22.10.13).

[4] Krolick CF, Amy JV. The all electric ship-10 years of progress reviewed. MERMar Eng Rev 2007:38-40. ISSN: 0047-5955.

[5] Dedes EK, Hudson DA, Turnock SR. Energy Policy 2012;40:204-18.

[6] Sattler G. Fuel cells going on-board. J Power Sources 2010;86:61-7.

[7] McConnell VP. Now, voyager? The increasing marine use of fuel cells. Fuel Cells Bull 2010;5:12-7.

[8] Leo TJ, Gonzalez O, Gomez-Bey A, Cadarso L, Navarro E. Fuel cells technology in marine and naval media. J Mar Technol Environ 2010;2:89-100.

[9] Han J, Charpentier JF, Tang T. State of the art of fuel cells for ship applications. In: 21th IEEE International Symposium on Industrial Electronics (ISIE), Hangzhou, China, May 28-31, 2012. p. 1456-61. Digital Object Identifier: 10.1109/ISIE.2012.6237306.

[10] Hamburg an der Alster. <www.zemships.eu>. (last accessed 22.10.13).

[11] Proton Motor Fuel Cell GmbH; <http://www.proton-motor.de/fileadmin/ downloads/FlyerShips-small.pdf>. (last accessed 22.10.13).

[12] Offshore Ship Designers; <http://www.offshoreshipdesigners.com/greentug/>. (last accessed 20.08.13).

[13] FellowSHIP; <www.vikinglady.no>. (last accessed 22.10.13).

[14] Eidesvik. Viking Lady; <http://www.eidesvik.no/viking-lady/category253. html>. (last accessed 22.10.13).

[15] Methapu; <http://ec.europa.eu/research/transport/projects/items/methapu_ en.htm>. (last accessed 22.10.13).

[16] Fontell E. Wärtsilä Fuel Cell Development Program. In: 8th Annual green ship technology conference, 21-22 March, 2011, Oslo, Norway; <http:// www.wartsila.com/file/Wartsila/1278519221899a1267106724867-WartsilaSP-ppt-2011-METHAPU.pdf>. (last accessed 22.10.13).

[17] Det Norske Veritas. Rules for classification of high speed, light craft and naval surface craft. Part 6 special equipment and systems-additional class. Ch23 fuel cell installations, July 2008, Rev. July 2013; <https://exchange.dnv.com/ publishing/RulesShip/2013-07/ts623.pdf>. (last accessed 22.10.13).

[18] Buy Y. Machinery concepts and LNG for meeting IMO Tier III rules. Wärtsilä Tech J 2011;1:31-8.

[19] Lewis EV. Principles of naval architecture. Jersery City: The Society of Naval Architects and Marine Engineers; 1988.

[20] Alvariño R, Azpíroz JJ, Meizoso M. El Proyecto Básico del Buque Mercante. Madrid: Fondo Editorial de Ingeniería Naval, COIN; 1997.

[21] Harrington RL. Marine engineering. Jersey City: The Society of Naval Architects and Marine Engineers; 1992.

[22] Flanagan GTH. Marine boilers. 3rd ed. Oxford: Heinemann Newnes; 1990.

[23] Taylor DA. Introduction to marine engineering. 2nd ed. Oxford: Butterworth Heinemann; 1996.

[24] ISO. Ships and marine technology. Air-conditioning and ventilation of accommodation spaces. Design conditions and basis of calculations. ISO 7547:2002. Geneve: ISO; 2002.

[25] Fontell E. Wärtsilä-led consortium wins marine SOFC funds. Fuel Cells Bull 2007;2:6.

[26] Bechtold R, Goodman M, Timbario T. Use of methanol as a transportation fuel, Arlington, VA. The Methanol Institute, 2007; <http://www.ourenergypolicy.
org/wp-content/uploads/2011/11/2007_11_MethanolInstitute_MethanolUse TransportationFuel.pdf>. (last accessed 22.10.13).

[27] Santin M, Traverso A, Magistri L. Liquid fuel utilization in SOFC hybrid systems. Appl Energy 2009;86:2204-12.

[28] Det Norske Veritas. Rules for classification of high speed, light craft and naval surface craft. Part 6 special equipment and systems-additional class. Ch32 tentative rules for low flashpoint liquid fuelled ship installations, July 2013 ; <https://exchange.dnv.com/publishing/RulesShip/2013-07/ts632.pdf>. (last accessed 22.10.13).

[29] Fontell E, Kivisaari T, Christiansen N, Hansen J-B, Pålsson J. Conceptual study of a $250 \mathrm{~kW}$ planar SOFC system for CHP application. J Power Sources 2004;131:49-56.

[30] Strazza C, Del Borghi A, Costamagna P, Traverso A, Santin M. Comparative LCA of metanol-fuelled SOFCs as auxiliary power systems on-board ships. Appl Energy 2010;87:1670-8.

[31] Ghirardo F, Santin M, Traverso A. Heat recovery options for onboard fuel cell systems. Int J Hydrogen Energy 2011:36:8134-42.

[32] Santin M, Traverso A, Magistri L, Massardo A. Thermoeconomic analysis of SOFC-GT hybrid systems fed by liquid fuels. Energy 2010;35:1077-83.

[33] Caterpillar Motoren GmbH. M 25C Project Guide Generator Set.Hamburg: Caterpillar, November 2011; <http://marine.cat.com/cda/files/953436/7/ Project\%20Guide\%20M25C\%20Genset_09.2011.pdf>. (last accessed 22.10.13).

[34] Woodyard D. Pounder's marine diesel engines and gas turbines. Burlington: Elsevier Butterworth-Heinemann; 2004.

[35] Pruitt KA, Braun RJ, Newman AM. Establishing conditions for the economic viability of fuel cell-based, combined heat and power distributed generation systems. Appl Energy 2011;111:904-20.

[36] Li M, Rao AD, Samuelsen GS. Performance and costs of advanced sustainable central power plants with CCS and $\mathrm{H}_{2}$ co-production. Appl Energy 2012;91:43-50.

\section{Glossary}

\author{
A: main deck area $\left(\mathrm{m}^{2}\right)$ \\ B: beam $(\mathrm{m})$ \\ D: depth (m) \\ DP: dynamic positioning \\ DWT: deadweight $(\mathrm{t})$ \\ FC: fuel cell \\ $\boldsymbol{K}_{\mathbf{n}}$ : simultaneity coefficient \\ $\boldsymbol{K}_{\boldsymbol{s r}}$ : operating range coefficient \\ $\boldsymbol{K}_{\mathbf{u}}$ : utilization coefficient \\ $\boldsymbol{L}_{\boldsymbol{O A}}$ : length overall $(\mathrm{m})$ \\ $\boldsymbol{L}_{\boldsymbol{p} p}$ : length between perpendiculars $(\mathrm{m})$ \\ MCFC: Molten Carbonate Fuel Cells \\ PAFC: Phosphoric Acid Fuel Cell \\ PEMFC: Polymer Electrolyte Membrane Fuel Cell \\ PSV: Platform Supply Vessel \\ $\dot{Q}$ : heat power $(\mathrm{kW})$ \\ $\dot{Q}_{\operatorname{cog} F C}$ : heat power obtained from FC through cogeneration $(\mathrm{kW})$ \\ SOFC: Solid Oxide Fuel Cell \\ T: draft $(\mathrm{m})$; temperature $(\mathrm{K})$ \\ $\boldsymbol{V}$ : sailing speed $(\mathrm{m} / \mathrm{s}, \mathrm{kn})$; volume $\left(\mathrm{m}^{3}\right)$ \\ $\boldsymbol{V}_{\boldsymbol{T} \boldsymbol{K}}$ : fuel tank capacity $\left(\mathrm{m}^{\mathbf{3}}\right)$
}

